University of Nebraska - Lincoln

DigitalCommons@University of Nebraska - Lincoln

USDA National Wildlife Research Center - Staff Publications
U.S. Department of Agriculture: Animal and Plant Health Inspection Service

January 2003

\title{
Low Mitochondrial DNA Variation in Double-crested Cormorants in Eastern North America
}

\author{
Juliann L. Waits \\ Owensboro, KY \\ Michael L. Avery \\ USDA-National Wildlife Research Center, michael.I.avery@aphis.usda.gov \\ Mark E. Tobin \\ USDA-APHIS-Wildlife Services \\ Paul L. Leberg \\ Department of Biology, University of Louisiana, Lafayette
}

Follow this and additional works at: https://digitalcommons.unl.edu/icwdm_usdanwrc

Part of the Environmental Sciences Commons

Waits, Juliann L.; Avery, Michael L.; Tobin, Mark E.; and Leberg, Paul L., "Low Mitochondrial DNA Variation in Double-crested Cormorants in Eastern North America" (2003). USDA National Wildlife Research Center Staff Publications. 198.

https://digitalcommons.unl.edu/icwdm_usdanwrc/198

This Article is brought to you for free and open access by the U.S. Department of Agriculture: Animal and Plant Health Inspection Service at DigitalCommons@University of Nebraska - Lincoln. It has been accepted for inclusion in USDA National Wildlife Research Center - Staff Publications by an authorized administrator of DigitalCommons@University of Nebraska - Lincoln. 


\title{
Low Mitochondrial DNA Variation in Double-crested Cormorants in Eastern North America
}

\author{
Juliann L. Warts ${ }^{1,4}$, Michael L. Avery ${ }^{2}$, Mark E. Tobin ${ }^{3}$ and Paul L. Leberg ${ }^{1}$ \\ 'Department of Biology, University of Louisiana, Lafayette, LA 70504, USA \\ ${ }^{2}$ USDA-National Wildlife Research Center, 2820 E. University Avenue, Gainesville, FL 32641, USA

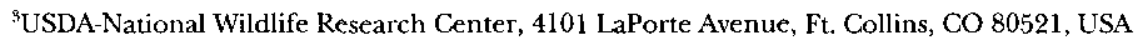 \\ ${ }^{4}$ Present address: 1330 Waverly Place, Owensboro, KY 42301, USA \\ Internet: Juilewaits@aol.com
}

\begin{abstract}
Double-crested Cormorant (Phalacrocorax auritus) numbers are increasing throughout eastern North America. We compared variation for five portions of $m+D N A$ to determine if genetic differences existed among portions of the breeding range that would need to be considered when formulating management programs. Sequences for four mtDNA regions were identical across sample locations; frequencies of two haplotypes of the mitochondrial Control Region were similar across sampling locations. There is no evidence of restricted gene flow among breeding areas, or between subspecies with different migratory patterns. Received 6 June 2002, accepted 25 November 2002.

Key words.-Double-crested Cormorants, Phalarrocorax aurilus, mtDNA, aquaculture, subspecies, migration.
\end{abstract}

Waterbirds 26(2): 196-200, 2003

The Double-crested Cormorant (Phalacrocorax auritus) is an abundant piscivore found across much of North America. Destruction of rookery sites, shooting, and reduced nest success from pesticide exposure were apparently responsible for a large decline in abundance of cormorants in the 19th and early 20th Centuries (Hatch 1995). This species was protected in 1972 under the United States-Mexican Convention for the Protection of Migratory Birds and Game Mammals (Trapp et al. 1995). Recently, numbers have expanded to historically high levels. In 1990, 1-2 million individuals were estimated to inhabit North America (Hatch 1995). This increase in numbers has been greatest in traditional breeding areas of the northeast and upper midwest of the United States and the maritime and prairie provinces of Canada (i.e., Chapdelaine and Bédard 1995; Krohn et al. 1995; Weseloh et al. 1995). Associated with this increase in numbers of breeding birds is a large increase in the number of individuals wintering in the southeastern United States (Brugger 1995; Hatch 1995; Jackson and Jackson 1995).

The recent increases in abundance and calls for control have resulted in a review of the status of the Double-crested Cormorant by the U.S. Fish and Wildlife Service (2001).
Management decisions are hampered by lack of knowledge of the genetic structure in this species (Hatch and Weseloh 1999). There is considerable genetic structure in the Great Cormorant (P. carbo; Goostrey et al. 1998), raising the possibility that Doublecrested Cormorants from different portions of the breeding range may also exhibit genetic differences.

Genetic structure could be of management concern because of the existence of two subspecies of Double-crested Cormorant in eastern North America with different migratory patterns. East of the Continental Divide, breeding colonies located in the northern U.S. and southern Canada and are classified as $P$. a. auritus (Lesson, 1831). This subspecies is strongly migratory (Bent 1922; Hatch 1995). On the basis of banding data (Kury and Cadbury 1970; Dolbeer 1991; Brugger 1995; Hatch 1995), the birds winter in the southeastern United States from North Carolina to Texas. Other breeding colonies, allopatric with $P$. a. auritus, occur in Florida and, to a lesser extent, in surrounding states (Brugger 1995; Hatch 1995; Reinhold et al. 1998; Hatch and Weseloh 1999). These birds are classified as $P$. a. floridanus (Audubon 1835), and individuals nesting in Florida are considered to be non-migratory 
(Bent 1922; Hatch 1995; Hatch and Weseloh 1999). Hatch (1995) and Hatch and Welsoh (1999) consider individuals nesting in Florida and the northern United States to be different populations. In addition to the differences in migratory patterns and the allopatry of the breeding sites of the two taxa, morphological analyses indicate that the Florida subspecies is smaller than $P$. a. auritus (Watson et al. 1991; Hatch 1995). It is unknown whether these subspecies, which have been distinguished on the basis of morphology and migratory behavior, are genetically differentiated. If there are large genetic differences between the subspecies, the nonmigratory $P$. a. floridanus might warrant special consideration for protection as evolutionary significant unit (Moritz 1994a). However, if migratory birds occasionally remain in the south to nest with resident birds, gene flow between the putative subspecies might be high enough to prevent genetic differentiation.

Mitochondrial DNA has been used to study phylogeographic relationships among populations of many species of animals (Avise 1994; Moritiz 1994b). Our objective was to determine if mtDNA variation exists within and between the two subspecies of Double-crested Cormorants inhabiting the eastern United States and Canada.

\section{METHODS}

To determine the extent of variation within or between subspecies, we initially sequenced DNA from three individuals sampled from each of three geographic regions, Florida, the Northern Prairie (North Dakota and Saskatchewan), and Great Lakes-St. Lawrence Seaway (Ontario and Quebec). Blood samples were collected from pre-fledgling birds during 1998-2000 (Fig. 1 ); investigators contributing blood were asked to sample only one individual per nest. DNA was isolated from these samples with Gentra's Puregene DNA Isolation protocol for whole blood with $7.5 \mathrm{M}$ ammonium acetate for DNA precipitation and resuspension in $\mathrm{dH}_{2} \mathrm{O}$.

Five regions of the $\mathrm{mtDNA}$ were sequenced. Ribosomal RNA primers $12 \mathrm{~L} 5$ and $12 \mathrm{H} 4$ were obtained from Hedges to examine the 12S RNA region (1994). The $16 \mathrm{~S}$ rRNA was amplified with primers $16 \mathrm{~L} 2$ and $16 \mathrm{H} 13$ (Hedges 1994); 16H12 was used as an internal sequencing primer (Hedges and Sibley 1994). Cytochrome $b$ L1484land H15149 primers and control region primers L15926 and H0065l were obtained from Kocher $e t a l$. (1989). The CO3-ND3 region was sequenced using primers L10647 and H11100 (Mindell et al. 1998). Amplifications and sequencing of florescently-labeled am-

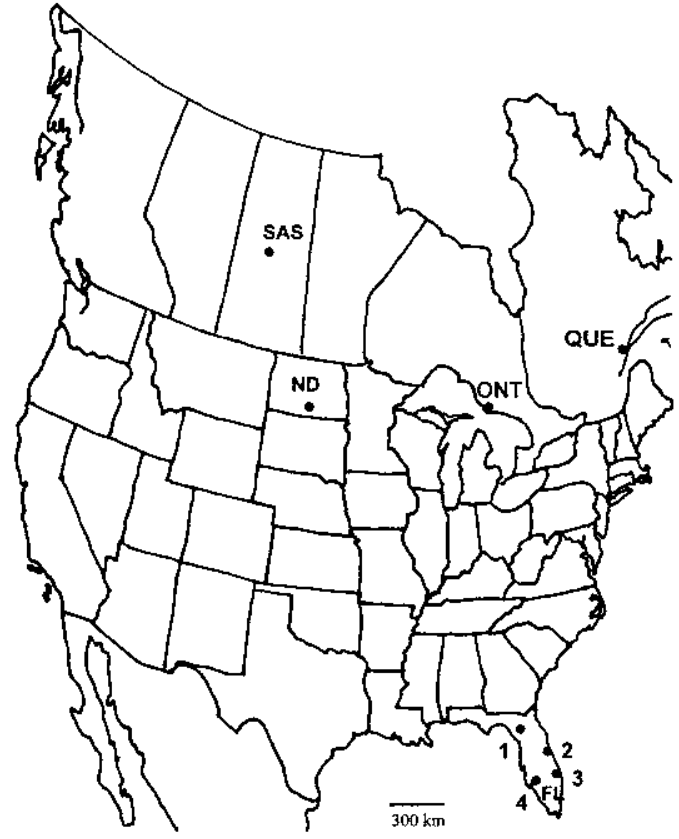

Figure 1. Geographic locations (dots) of individuals used to examine the miDNA variation of the Doublecrested Cormorant (Phalacrocorax auritus). FL1-St. Martins' Keys, Citrus Co. $\left(\mathrm{N}^{2} 8^{\circ} 49\right.$, W82 39$)$; FL2Lake Kissimmee, Osceola Co. $\left(\mathrm{N}^{\circ} 8^{\circ} 47\right.$, W81 ${ }^{\circ} 03$ ); FL 3 - Cocoa Beach, Brevard Co. $\left(\mathrm{N}^{\circ} 8^{\circ} 19\right.$, W80 $\left.{ }^{\circ} 36\right)$; FLA Sanibel Island, Lee Co. $\left(\mathrm{N}^{\circ} 6^{\circ} 26\right.$, W82 $\left.{ }^{\circ} 06\right)$; NDChase Lake (N47 ${ }^{\circ} 00.70$, W99 $\left.9^{\circ} 27.20\right)$; SAS-Dore Lake (N54 ${ }^{\circ}$ 29, W108 ${ }^{\circ} 16$ ); QUE-St. Lawrence River $\left(\mathrm{N70}^{\circ} 36, \mathrm{~W}^{\circ} 7^{\circ} 23\right)$; $\mathrm{ONT}_{-}-$Steamboat Island, Lake Superior $\left(\mathrm{N}^{\circ} 6^{\circ} 39, \mathrm{~W}^{\circ} 4^{\circ} 36\right)$.

plification products were preformed using AmpliTaq Gold polymerase and standard protocols provided by the manufacturer (Applied BioSystems, ABI). Sequences, generated on an ABI 310 Genetic Analyzer, were aligned with published avian $\mathrm{mtDNA}$. Aligned sequences were translated into amino acid sequences; no premature stop codons were found in coding regions.

\section{RESULTS}

No variation was found in the 12S rRNA, 16S rRNA, CO3-ND3, and cytochrome b sequences obtained from the three locations we sampled (Table 1). However, a single base insertion was found among sequences of the mitochondrial control region (i.e., D-loop) of the mtDNA. This region was sequenced for nine additional individuals, including individuals from sites in Florida that were not analyzed previously, to assess the distribution of the two haplotypes (Table 1, Fig. 1). GENEPOP was used to examine variation in 
Table 1. Sequences examined for Double-crested Cormorant mtDNA for three portions of the breeding range. Numbers of individuals with the same sequence are listed by sampling region, along with the accession number of sequences deposited in Genbank.

\begin{tabular}{|c|c|c|c|c|c|}
\hline \multirow[b]{2}{*}{ Sequence } & \multirow{2}{*}{$\begin{array}{l}\text { Fragment } \\
\text { length }^{1}\end{array}$} & \multicolumn{3}{|c|}{ Numbers of individuals sharing sequence } & \multirow{2}{*}{$\begin{array}{c}\text { Genbank } \\
\text { Accession } \\
\text { Number }\end{array}$} \\
\hline & & Florida & Northern Prairie ${ }^{2}$ & Great Lakes-St.Lawrence Seaway ${ }^{3}$ & \\
\hline 12s RNA & 414 & 3 & 3 (2 from ND, 1 from SAS) & 3 (from QUE) & AF373588 \\
\hline CO3-ND3 & 461 & 3 & 3 (2 from ND, 1 from $\mathrm{SAS})$ & 3 (2 from QUE, 1 from ONT) & AF373589 \\
\hline Cytochrome b & 342 & 3 & $3(3$ from ND) & 3 (1 from QUE, 2 from ONT) & AF373590 \\
\hline 16 sNA & 992 & 3 & 3 (2 from ND, 1 from SAS) & 3 (2 from QUE, 1 from ONT) & AF373591 \\
\hline \multicolumn{6}{|l|}{ Control region } \\
\hline Haplotype A & 355 & 4 & $2(1$ from $N D, 1$ from $S A S)$ & 4 (2 from QUE, 2 from ONT) & AF373592 \\
\hline Haplotype B & 356 & 2 & 4 (2 from ND, 2 from $\mathrm{SAS}$ ) & 2 (1 from QUE, 1 from ONT) & AF373593 \\
\hline
\end{tabular}

haplotype distribution in the three geographic samples. There was no apparent difference in the frequency of the two control region haplotypes among samples $(\mathrm{P}=0.59)$ based on randomization test from GENEPOP (Raymond and Rousset 1995). Both variants occurred at a high frequency in each sampling location (Table 1).

\section{Discussion}

Little variation was found in five regions of mtDNA sequenced for samples from either subspecies. While it was not surprising that conservative regions of the mtDNA such as the CO3-ND3, 16S and 12S exhibited no differentiation among individuals, some of these slowly evolving regions have exhibited sequence differentiation among disjunct populations of other taxa (e.g., Matthee and Fleming 2002; Paulo et al. 2002). More striking is the lack of differentiation between the two subspecies at the cytochrome $b$ and control regions. These regions of the mtDNA evolve relatively rapidly and have been used to detect population structure in many other avian species (e.g., Wenink et al. 1996; Buerkle 1999; Kirchrnann et al. 2000; Burg and Croxall 2001).

One reason for a lack of genetic differentiation might be high gene flow, but this is difficult to assess because there is little variation in the regions of mtDNA we examined. With the limited sample sizes used in this study, it would be difficult to detect anything other than large shifts in haplotype frequencies. However, sample sizes were sufficient to identify major phylogenetic subdivisions if they had existed. Widespread distribution of both of the control region haplotypes provides stronger evidence that there is gene flow among sampling locations, this could be due to recent population expansion in the last 30 years. While most of the expansion in numbers has occurred in traditional breeding areas, a few colonies have become established between the summer ranges of the two subspecies (Hatch 1995). One such nesting aggregation occurs in North Carolina where individuals are intermediate in morphology between $P$. a. auritus and $P$. a. floridanus, suggesting the possibility of gene flow (Hatch 1995). Banding data shed little light on the amount of gene flow among $P, a$. auritus and $P$. a. floridanus. Movement studies have shown that individuals do not maintain roostsite specificity in wintering areas (King 1996) and they spread out over large geographic areas when migrating north to breed (Dolbeer 1991; Brugger 1995). Although banding returns indicate that adults often nest near their natal colonies, several instances of long distance dispersal to other breeding colonies have been observed (Dolbeer 1991).

If $P$. a. floridanus was isolated from the migratory $P$. a. auritus for a prolonged period, sequence divergence would be expected. Buerkle (1999) found substantial divergence 
between migratory Prairie Warblers (Dendroica discolor) nesting in the northern United States and non-migratory populations in Florida, suggesting that the migratory and nonmigratory forms have been isolated since the late Pleistocene. Unless rates of mtDNA evolution in warblers and cormorants are dramatically different, non-migratory $P . a$. floridanus must have been isolated much more recently than the Pleistocene, and raise the possibility that gene flow is ongoing.

This study provides no evidence to justify managing $P$. a. floridanus differently than $P$. a. auritus or for treating them as separate subspecies. It is possible that gene flow between the subspecies is large and that differences in size of cormorants from Florida and northern individuals is due partially to environmental influences on growth, as has been documented in other birds (James 1983).

Subspecies are expected to exhibit genetic differentiation (Mayr 1963, O'Brien and Mayr 1991; Ball and Avise 1992). While differences in mtDNA would have been strong support to the taxonomic distinction of $P$. a. floridanus and $P$. a. auritus, the lack of sequence differentiation makes this taxonomic distinction ambiguous (Ball and Avise 1992). The mtDNA sequences we examined are all part of one non-recombining genetic unit and it is possible that independent nuclear genes would exit genetic differentiation concordant with the geographic ranges of the two taxa. Given the limited amounts of $m$ tDNA variation that were detected, our understanding of the taxonomic status of these putative subspecies would benefit from additional analyses with more polymorphic nuclear genetic markers.

\section{ACKNOWLEDGMENTS}

We would like to thank all those individuals who collected samples including D.V. C. Weseloh, Environment Canada; J. H. Bédard, University Laval; and B. A. Hanbidge, Ducks Unlimited Canada. We thank I. Lovette, C. Williams, S. Werner, and two anonymous reviewers for critical comments on an earlier draft of this manuscript. Funding was provided by the USDA's National Wildlife Research Center; NSF DEB 9907567 provided support during manuscript preparation.

\section{LITERATURE CITED}

Avise, J. C. 1994. Molecular markers, Natural History and Evolution. Chapman \& Hall, New York.
Ball, R. M. and J. C. Avise 1992. Mitochondrial DNA phylogeographic differentiation among avian populalions and the evolutionary significance of subspecies. Auk 109: 626-636.

Bent, A. C. 1922. Life histories of North American petrels and pelicans and their allies. U.S. National Museum Bulletin 121.

Bucrkle, C. A. 1999. The historical pattern of gene flow among migratory and non-migratory populations of prairie warblers Aves: Parulinae. Evolution 53: 19151924.

Brugger, K. E. 1995. Double-crested Cormorants and fisheries in Florida. Colonial Waterbirds 18: 110-117, Special Issue 1.

Burg, T. M. and J. P. Croxall. 2001. Global relationships amongst black-browed and grey-headed albatrosses: analysis of population structure using mitrochondrial DNA and microsatellites. Molecular Ecology 10: 2647-2660.

Chapdelaine, G. and J. Bédard. 1995. Recent changes in the abundance and distribution of the Double-crested Cormorant in the St. Lawrence River, Estuary and Gulf, Quebec, 1978-1990. Colonial Watcrbirds 18:70-77, Special Issue ].

Dolbeer, R. A. 1991. Migration patterns of double-crested cormorants east of the Rocky Mountains. Journal of Field Ornithology 62: 83-93.

Goostrey, A., D. N. Carss, L. R. Noble and S. B. Piertney. 1998. Population introgression and differentiation in the great cormorant Phalacrocorax carbo in Europe. Molecular Ecology 7: 329-338.

Hatch, J.J. 1995. Changing populations of Double-crested Comorants. Colonial Waterbirds 18: 8-24, Special Issue 1.

Hatch, J. J. and D. V. Weseloh. 1999. Double-crested Cormorant (Phalacrocorax auritus). In [A. Poole and F. Gill, Eds.], The Birds of North America. The Birds of North America, Inc., Philadelphia.

Hedges, S. B. 1994. Molecular evidence for the origin of birds. Proceedings of the National Academy of Science USA 91: 2621-2624.

Hedges, S. B. and C. G. Sibley. 1994. Molecules vs. morphology in avian evolution: The case of the "pelecaniform" birds. Proceedings of the National Academy of Science USA 9]: 9861-9865.

Jackson, J. A and B. J. S. Jackson. 1995. The Doublecrested Cormorant in the south-central United States: Habitat and population changes of a feathered pariah. Waterbirds 18: 118-130. Special Issue 1.

James, F. C. 1983. Environmental component of morphological differentiation in birds. Science 221: 184186.

King, D. T. 1996. Movements of Double-crested Cormorants among winter roosts in the delta region of Mississippi. Journal of Field Ornithology 67: 205-211.

Kocher, T. D., W. K. Thomas, A. Meyer, S. V. Edwards, S. Paabo, F. X. Villablanca and A. C. Wilson. 1989. Dynamics of mitochondrial DNA evolution in animals: Amplification and sequencing with conserved primers. Proceedings of the National Academy of Science USA. 86: 6196-6200.

Krohn, W. B., R. B. Allen, J. R. Moring and A. E. Hutchinson. 1995. Double-crested Cormorants in New England: Population and management histories. Colonial Waterbirds 18: 99-109, Special Issue 1.

Kury, C. R. and J. M. Cadbury. 1970. The winter distribution of Maine's Double-crested Cormorants. Auk 87: 815 . 
Matthee, C. A. and A. F. Flemming. 2002. Population fragmentation in the southern rock agama, Agama atra: more evidence for vicariance in southem Africa. Molecular Ecology 11: 465-471.

Mayr, E. 1963. Animal species and evolution. Belknap Press, Harvard, Cambridge.

Mindell, D. P., M. D. Sorenson and D. E. Dimcheff 1998. An extra nucleotide is not translated in mitochondrial ND3 of some birds and turtles. Molecular Biology and Evolution 15: 1568-1571.

Moritz, C. 1994a. Defining evolutionary significant units for conservation. Trends in Ecology and Evolution 9: 373-375.

Moritz, C. 1994b. Applications of mitochondrial DNA analysis in conservation: a critical review. Molecular Ecology 3: 403-413.

O'Brien, S. J. and E. Mayr. 1991. Bureaucratic mischief: recognizing endangered species and subspecies. Science 251: 1187-1188

Paulo, O. S., I. Pinto, M. W. Bruford, W. C. Jordan and R. A. Nichols. 2002. The double origin of Iberian peninsular chameleons. Biological Journal of the Linnean Society 75: 1-7.
Raymond, M. and F. Rousset. 1995. Genepop (Version1.2): Population genetics software for exact tests and ecumenicist. Journal of Heredity 86: 248-249.

Reinhold, D. S., A. J. Mueller and G. Elis. 1998. Observations of nesting Double-crested Cormorants in the delta region of Mississippi. Colonial Waterbirds 21: 450-451.

Trapp, J. L., T. J. Dwyer, J. J. Doggett and J. G. Nickum. 1995. Management responsibilities and policies for cormorants: United States Fish and Wildlife Service. Colonial Waterbirds 18: 226-230, Special Issue 1.

U.S. Fish and Wildlife Service. 2001. Draft Environmental Impact Statement: Double-crested Cormorant Management. U.S. Department of Interior, Fish and Wildlife Service, Arlington.

Watson, G. E., S. L Olson and J. R. Miller. 1991. A new subspecies of the Double-crested Cormorant, Phalacrocorax auritus, from San Salvador, Bahama Islands. Proceedings of the Biological Society of Washington, 104: 356-369.

Wenink, P. W., A. J. Baker, H.-U. Rosner and M. G. J. Tilanus. 1996. Global mitochondrial DNA phylogeography of holarctic breeding Dunlins (Calidris alpina). Evolution 50: 318-330. 